\title{
Using space-time scan statistic for studying the effects of COVID-19 in Punjab, Pakistan: a guideline for policy measures in regional agriculture
}

\author{
Sajjad Hussain ${ }^{1}(1) \cdot$ Muhammad Mubeen $^{1} \cdot$ Ashfaq Ahmad $^{2} \cdot$ Shah Fahad $^{3} \cdot$ Wajid Nasim $^{4} \cdot$ Hafiz Mohkum Hammad $^{5}$. \\ Ghulam Mustafa Shah ${ }^{1} \cdot$ Behzad Murtaza $^{1} \cdot$ Muhammad Tahir $^{1} \cdot$ Saima Parveen $^{5}$
}

Received: 20 August 2021 / Accepted: 4 November 2021 / Published online: 20 November 2021

(c) The Author(s), under exclusive licence to Springer-Verlag GmbH Germany, part of Springer Nature 2021

\begin{abstract}
Pakistan is included in top 50 countries which are estimated to face serious agriculture and food deficiency related challenges due to the worldwide pandemic coronavirus 2019 (COVID-19). The aim of this study was to evaluate the effects of COVID-19 on food supply chain and agriculture in Punjab, Pakistan, by using space-time scan statistic (STSS). A survey was conducted at 720 points in different districts of the province. The STSS detected "active" and emerging clusters that are current at the end of our study area-particularly, 17 clusters were formed while adding the updated case data. Software ArcGIS 10.3 was used to find relative risk (RR) values; the maximum RR value was found to be 42.19 and maximum observed cases 53,265 during June 15-July 1, 2020. It was not always necessary that if the number of active cases in Punjab increased, there should be higher relative risk for more number of districts and vice versa. Due to the highest number of cases of COVID-19 and RR values during July, mostly farmers faced many difficulties during the cultivation of cotton and rice. Mostly farmers (72\%) observed increase in prices of inputs (fertilizers and pesticides) during lockdown. If the supply chain of agriculture related inputs is disturbed, farmers may find it quite difficult to access markets, which could result in a decline in production and sales of crops and livestock in study area. It is suggested that to protect the food security and to decrease the effect of the lockdown, Punjab government needs to review food policy and analyse how market forces will respond to the imbalanced storage facilities and capacity, supply and demand and price control of products. The findings of this study can also help policy-makers to formulate an effective food security and agriculture adaptation strategy.
\end{abstract}

Keywords COVID-19 $\cdot$ Food security $\cdot$ STSS $\cdot$ Agriculture $\cdot$ Farmers' perception

\begin{tabular}{|c|c|}
\hline \\
\hline \multicolumn{2}{|r|}{$\begin{array}{l}\text { Responsible Editor: Lotfi Aleya } \\
\triangle \text { Sajjad Hussain }\end{array}$} \\
\hline \multicolumn{2}{|r|}{$\begin{array}{l}\text { Muhammad Mubeen } \\
\text { muhammadmubeen@cuivehari.edu.pk }\end{array}$} \\
\hline \multicolumn{2}{|c|}{$\begin{array}{l}\triangle \text { Saima Parveen } \\
\text { Chsaima801@gmail.com }\end{array}$} \\
\hline 1 & $\begin{array}{l}\text { Department of Environmental Sciences, COMSATS } \\
\text { University Islamabad, Vehari Campus, Islamabad } 61100 \text {, } \\
\text { Pakistan }\end{array}$ \\
\hline 2 & $\begin{array}{l}\text { Asian Disaster Preparedness Center (ADPC), Bangkok, } \\
\text { Thailand }\end{array}$ \\
\hline
\end{tabular}

3 Department of Agronomy, The University of Haripur, Haripur 22620, Pakistan

4 Department of Agronomy, Faculty of Agriculture and Environment, The Islamia University of Bahawalpur (IUB), Bahawalpur, Pakistan

6 Department of Agronomy, Muhammad Nawaz Sharif University of Agriculture, Multan 66000, Pakistan

5 Department of Computer Science, Institute of Southern Punjab, Multan, Pakistan 


\section{Introduction}

Coronavirus 2019 (COVID-19) disease is one of the most serious diseases (being contagious in nature) which is newly exposed and spread across China in December 2019; it has global significance. As the COVID-19 pandemic prevailed during 2020, resilience of food supply chains has got significant attention during lockdown (Bizoza and Sibomana 2020; Deaton and Deaton 2020; WFP (world food program) 2020a; Zhu et al. 2019; Mohan Viswanathan et al. 2021). The COVID-19 is predicted as a health risk that has created a big challenge for agriculture and food security (Boulos and Geraghty 2020; Chan et al. 2020; Dlamini et al. 2020; Hafiz et al. 2020; Mhlanga and Ndhlovu 2020). Farmers were unable to buy the agricultural items, markets were locked, and food supply chains were limited due to trade restrictions and sick truck drivers facing quarantines (Alvarez-Mendoza et al. 2020; Miller 2020; Wu et al. 2020; Shankar et al. 2021). Furthermore, decreased incomes of the farmers rendered them unable to hire farm labour, which was extremely limited because joint work was banned in fields (Arndt et al. 2020; Khan et al. 2020c; Kansiime et al. 2020). The COVID-19 has direct impacts on household income as well as future expectations thereof, as private and public businesses and workplaces are closed mainly to enforce "social distancing" (Guo et al. 2020; Spinelli and Pellino 2020; Karunanidhi et al. 2021; Murugesan et al. 2020a, b; Stephens et al. 2020). Employees also left their jobs due to health concerns for their families and themselves (Béné 2020; Khan et al. 2020b; Kumar et al. 2020; Sarfo and Karuppannan 2020). The COVID-19 has significant characteristics that make its harmful impacts unique for income generation and employment in comparison to the earlier income shocks, for example, economic crisis in 2008 (Boughton et al. 2020; Kreutz et al. 2020; Niles et al. 2020; Richards and Rickard 2020; Siche 2020; Mollalo et al. 2020).

Space-time scan statistic (STSS) is a new technique to detect the "active" and emerging clusters of various diseases, which can be utilized for observation during an on-going epidemic (Masrur et al. 2020). The STSS can identify groups that are "active" in each location; but as more information (like confirmed cases) becomes presented, STSS can be repeated to confirm the occurrence as well as track the clusters in space and time, update relative risks (RR) for every area effected due to disease and detect new emerging clusters (Desjardins et al. 2020). The important purpose of using a STSS (rather than reflective) is to only focus on significant clustering that is "active" or current at the time of the analysis, which disregards clusters that may have existed previously and are no longer a public health threat (Arab-Mazar et al. 2020; Lakhani 2020). The STSS has been used to detect emerging clusters of shigellosis, measles, thyroid cancer and syndromic observation (Hohl et al. 2020). Geographic information systems (GIS) has been applied to the field of agriculture in various domains including land management, regional agricultural resource information and planning (Hussain 2018; Majeed et al. 2021), management of grain distribution and decisionmaking related to food production, research in the areas of agricultural production potential and crop yield estimation (Hussain et al. 2020b; Khan et al. 2020d; Rezaei et al. 2020; Hussain and Karuppannan 2021). In the fight against COVID-19, GIS has played a significant role in different aspects, for example tracking of confirmed cases of COVID19 , rapid visualization of COVID data and combination of multi-source big data (Sun et al. 2020; Zhou et al. 2020; Zhang et al. 2020). The GIS tools could be used as an imagining help to map the spatial spreading of the various dataset including STSS, the resources available and risk factors for prevention and treatment (Karuppasamy et al. 2020); Hussain et al. 2020c).

Agriculture is a very essential sector, providing food to the rapidly increasing population in Punjab, the major agricultural province of Pakistan (Ahmad et al. 2020; Sabagh et al. 2020; Islam et al. 2021). Agriculture can play a significant role in economic growth in the Punjab (Hussain et al. 2020a; Mubeen et al. 2021; Ahmed et al. 2022; Naz et al. 2022). The farmers are playing an important role in sustainability of food security and agriculture in Punjab (Pakistan; Malik et al. 2020); they are providing raw material for exports, yet they are facing a great deal of challenges (Latif 2020; Mehmood et al. 2021; Din et al. 2022). Different reports show that the non-availability of labour may disturb some harvesting activities, mostly in Pakistan where wheat and pulses are to be harvested in the month of April (Ali and Rahut 2020; Khan et al. 2020a; Masood et al. 2022). In Punjab, cultivated area decreased along with farmers' incomes during lockdown because of COVID-19 (WHO (World Health Organization) 2020; Shahzad et al. 2021). Fruit and vegetable growers were mostly affected because they could not sell their produce due to market closings and limited movement of goods (Khaliq et al. 2020; Akram et al. 2022; Hussain et al. 2022). So, Punjab needs to be prepared for potential surge about agriculture in upcoming months. Here, we focused on food security of post-COVID-19 as well as agriculture supply chain management of grains, pulses, fruits and vegetables, impacted by lockdown. The aims of this research were as follows:

1. Analyse the trend and relative risk (RR) in the spread of COVID-19 by using STSS. 
2. Study the impacts of COVID-19 on agriculture and food supply chain in Punjab (Pakistan).

\section{Materials and methods}

\section{Study location}

The study location was composed of Punjab province (Pakistan) shown in Fig. 1. Punjab is the greatest populated province of Pakistan, with a population of about 110 million in 2017. Punjab is the 2 nd biggest province by area (with an area of 205,344 square kilometres) after Baluchistan province. It is bounded by Khyber Pakhtunkhwa province to the west, the Baluchistan province to the southwest, Sindh province to the south and the Azad Kashmir and Islamabad Capital in the north. Punjab province is also bounded by province of Rajasthan and Indian Punjab to the east as well as Jammu and Kashmir in the north. In Pakistan, the most agricultural province is Punjab where cotton and wheat are the most cultivated crops. Mango orchards are also found in province of Punjab that make Pakistan the world's 4th largest producer of mangoes. Agriculture is fundamental to Punjab's economy, contributing over 19\% of GDP and 39\% of the labour force of Pakistan (PBS 2020). The COVID-19 epidemic was initially described in Wuhan, China, and has spread to more than 200 countries till now. In Punjab, the first case was reported by 15th March 2020 at Lahore, and since then a fast increase in COVID cases has been observed throughout the province which has disturbed not only the

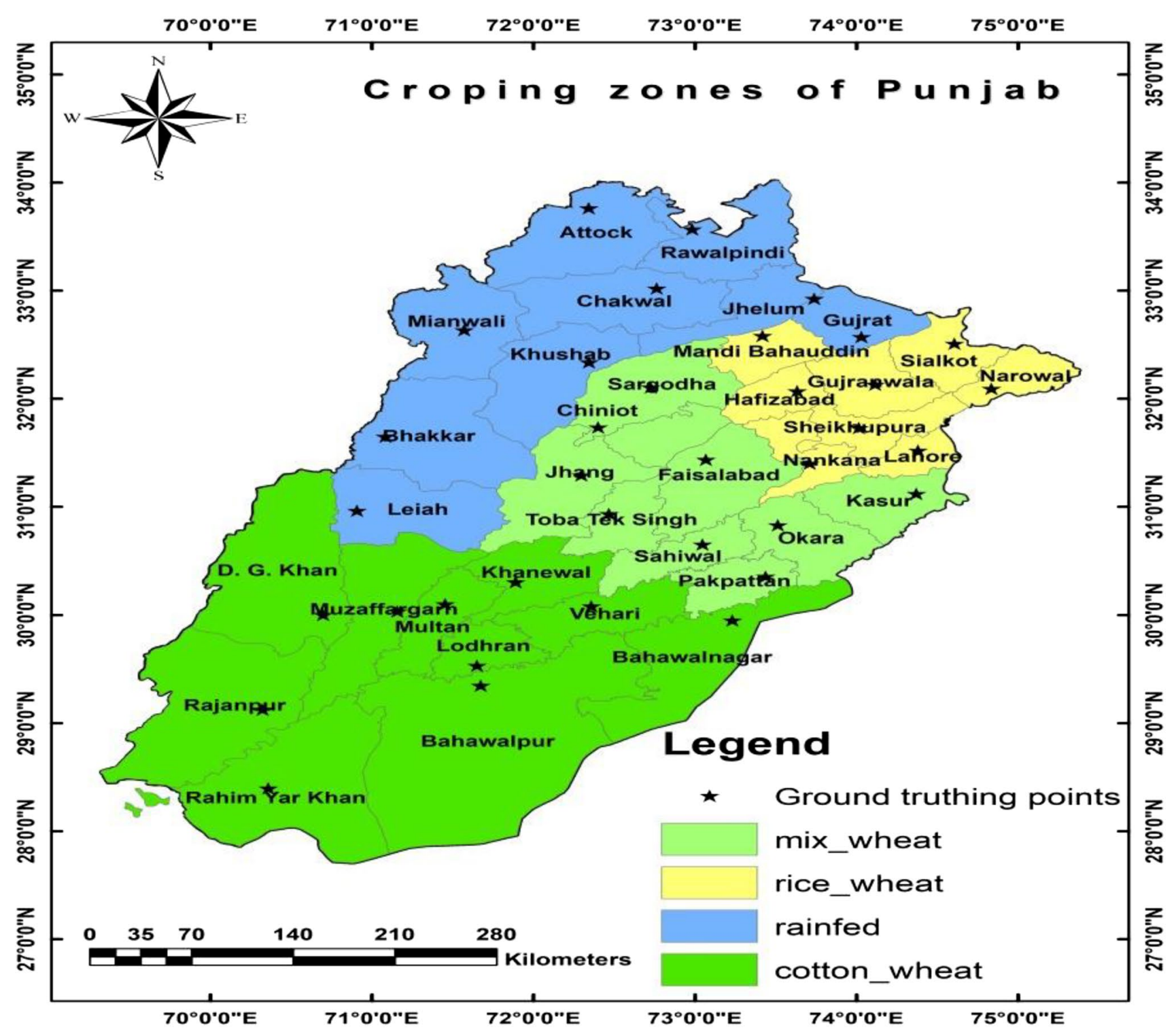

Fig. 1 Study area map of Punjab 
people of urban areas but the rural community as well, resulting in devastating effect on agriculture.

\section{Data collection and analysis}

This research is primarily based on the survey which was conducted from farmers all over the province of Punjab (Pakistan). A survey was conducted at 720 points in different districts of Punjab; so the study results are based on this survey and are also based on some data from different websites, newspapers, agriculture department and Pakistan Bureau of Statistics (PBS) which conducted different surveys in Pakistan. The survey was conducted via a web form, which was available on PC/desktop and mobile phone. The information collection duration was inclusive of April to August 2020. The survey was dispersed usually through face to face, via email and by communication channels and social media; the opinion was obtained by the participants including farmers and expert persons related to agriculture and Ministries of Agriculture. Respondents were imagined live on a communicating dashboard as well as regularly observed to confirm their validity on the basis of cross referencing with previous knowledge and secondary data (AYRA 2020). Data were noted on the survey data sheet, i.e. longitude, latitude points by using global positioning system (GPS) software through smart phone, class name and three geo-tagged pictures at every survey location. These collected data also used independent information for accuracy and analysis by different softwares. After collecting these data, data were analysed, and graphs were made using Microsoft word and excel. Additionally, information used in this research were patients of COVID-19 disease in Punjab, Pakistan, from March 15 2020 to January 12021 attained from the Health Department of Punjab (WHO (World Health Organization) 2020).

\section{Space-time scan statistic}

To detect the space-time clusters that are still occurring or "active", we utilized the prospective version of the Space-time scan statistic (STSS) (Desjardins et al. 2020). The STSS identifies the COVID-19 that are still active (excess risk still present) in our dataset during the previous months. We also perceive space-time clusters of COVID19 that are emerging and "disregard" clusters that do not have a statistically important excess RR (for example more detected than expected COVID-19 cases) in study area. In other words, the STSS estimates potential clusters that are still taking place at the end of November. Next, every cylinder is extended until a maximum temporal, and spatial upper bound is reached, while every cylinder is a potential cluster. We set the upper bounds to have a maximum spatial and temporal scanning window size of $10 \%$ of the population at-risk to avoid extremely large clusters and $50 \%$ of the study duration, relatively. An unknown large number of cylinders of different spatial and temporal sizes are produced around each centroid until the maximum temporal and spatial thresholds are reached; the expected and observed case counts are computed within every cylinder, which are derived from the total number of centroids captured in each cylinder. We selected the discrete Poisson data model, where we expected that the COVID-19 cases followed a Poisson distribution according to the population of the study area. The null hypothesis $\mathrm{H}_{0}$ states that the model reflects a constant risk with an intensity $\mu$, which is proportional to the at-risk population. The alternative hypothesis $\mathrm{H}_{\mathrm{A}}$ states that observed COVID-19 cases exceed the expected number of cases derived from the null model (elevated risk within a cylinder). The number of expected COVID-19 cases $(\mu)$ under the null hypothesis $\mathrm{H}_{0}$ is derived as shown in Eq. 1 (Masrur et al. 2020):

$\mu=p * \frac{C}{P}$

where $p$ the population in $i, C$ the total COVID-19 cases in the Punjab and $P$ the over-all projected population in the study area. Note that the model assumes that the population is static for every district at any time of period. Moreover, the STSS uses various cylinder sizes, and the cylinder with the highest likelihood ratio (maximum) is the most likely cluster. To circumvent the assumption that the relative risk of COVID-19 is homogenous throughout an important space-time cluster, we also report and visualize the RR for every district of Punjab that belongs to a cluster. The (RR) for each location belonging to a cluster is derived from Eq. 2 (Martines et al. 2021):

$$
R R=\frac{c / e}{(C-c) /(C-e)}
$$

where $c$ is the overall number of COVID-19 cases in the study area, $e$ is the total number of expected cases in the study area and $C$ is the total number of observed cases in the province of Punjab. The RR is the relative risk within a location divided by the risk outside of the location (i.e. everywhere else). The testified clusters have a RR, which is derived the same way as Eq. (2); but the clusters RR is estimated risk (observed/expected) divided by the risk outside of the cluster. The results classify statistically important emerging clusters of COVID-19 in the study area for each district from March 2020 to November 2020. 


\section{Results and discussion}

\section{Trend and relative risk of COVID-19}

The novel COVID-19 has spread relatively at faster rate from March to July 2020, and the number of reported infections was 53,265 on July 1 (the highest figure so far). The number of confirmed cases increased during the months of June and July, mostly due to people having travel histories of the affected places. On July 15 , total confirmed cases were reported to be 38,786 which decreased as compared to June. At the end of July, observed COVID-19 cases decreased in different areas of the study region. The decrease in cases continued until September 15, but afterwards, the disease spread at increasing rate and reached to the cases 24,552 on December 1, 2020. On January 15, 2021, total confirmed cases were reported to be 17,084 which decreased as compared to December and November. At the end of February, observed COVID-19 cases decreased in different areas of the study region. But during March 2021, COVID-19 cases also again increased as compared to last month which is called the 3rd wave of COVID-19 in Punjab. On March 15, COVID-19 cases were reported 38,647, due to high number of cases; different districts had a lockdown. Although there seems to be some decline in the number of cases after December 1, there are still chances the disease may upsurge (Fig. 2). In several district hospitals, nearly $90 \%$ of ventilators and oxygen beds are already occupied, while some hospitals are refusing new patients as $100 \%$ of beds allocated for coronavirus patients are already taken, according to ministry officials. Pakistan is set to receive millions of COVID-19 vaccine doses from various countries in the coming weeks to speed up its slow immunization campaign. As of October 20, 2021 , out of its population of 210 million, nearly 100 million people, including health professionals and people above 18 years old, have got their first dose of vaccine inoculated.
The lockdown is up again and have left millions of daily wage labourers, farmers, etc. unemployed.

Table 1 presents the features of the statistically important emerging STSS of COVID-19 in each district of Punjab from March to November 2020. Clusters were based on the mean values of all districts of Punjab with a RR $>1$ (i.e. more detected than expected cases). Punjab has an RR of 0.049 with 63 detected cases during March 1 to 15 in Punjab (cluster 1). Cluster 3 contains RR of 1.91 and 2,413 observed cases. Cluster 5 contains RR of 10.03 and 12,661 observed cases in the study area during May 1-15. Cluster 8 contains maximum RR values of 42.19 and maximum observed cases 53,265 during June 15-July 1, 2020. During this cluster, almost all the districts in Punjab contained $R R>1$. After this cluster, it is observed that RR values decreased because observed values also decreased in the study area. The cluster 10 contains RR of 9.96 and 12,674 observed cases during July 15-August 1 . In cluster 12, RR of 3.52 and 4,440 cases were observed during August 15-September 1. Cluster 14 contains values like (observed cases $=4,412)$ and $(\mathrm{RR}=3.49)$ and showed the decreasing trend in COVID-19 cases in study area. In cluster 17, trend of COVID-19 cases showed increase as pervious trend (like observed cases $=13,269$ and $R R=10.51$ ) during Nov $1^{\text {st }}-$ Nov $15^{\text {th }} 2020$ and almost 10 districts have RR $>1$ in study area. By comparison of Table 1 and Fig. 2, it is clear that it was not always necessary that if the number of active cases in Punjab increased, there should be higher relative risk for more number of districts and vice versa. This can be found at clusters 4 and cluster 10. In cluster 4 (April 15 to May 1), although the number of active cases was on increase in the whole Punjab, the number of districts having RR $>1$ decreased as compared to cluster 3 (decreased from 5 to 3 ). Similarly, in cluster 10 (July 15 to August 1), the number of active cases was decreasing for the study region but the districts having RR $>1$ increased from 23 (cluster 9) to 27. So, STSS provides valuable information regarding potential of the disease spread in a given region and may be used as a
Fig. 2 Trend of COVID-19 in Punjab, Pakistan

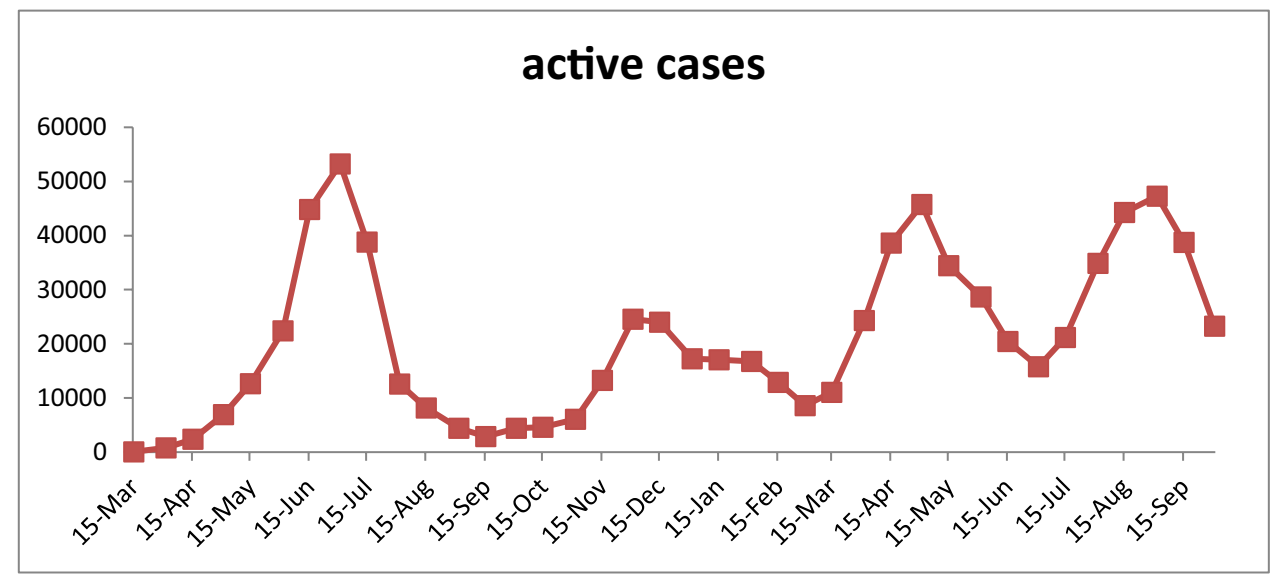


Table.1 space-time scan statistic (SPSS) of COVID-19

from March to November 2020 in Punjab $(\mathrm{RR}=$ relative risk)

\begin{tabular}{|c|c|c|c|c|c|}
\hline Cluster & Duration & Observed cases & Expected cases & $\mathrm{RR}$ & $\begin{array}{l}\text { Districts } \\
\text { with } \\
\text { RR }>1\end{array}$ \\
\hline 1 & March 1-March 15 & 63 & 1.24 & 0.049 & 0 \\
\hline 2 & March 15-April 1 & 810 & 16.04 & 0.64 & 1 \\
\hline 3 & April 1-April 15 & 2413 & 47.78 & 1.91 & 5 \\
\hline 4 & April 15-May 1 & 6916 & 136.95 & 5.48 & 3 \\
\hline 5 & May 1-May 15 & 12,661 & 250.72 & 10.03 & 9 \\
\hline 6 & May 15-June 1 & 22,417 & 443.90 & 17.75 & 21 \\
\hline 7 & June 1-June 15 & 44,846 & 888.03 & 35.52 & 30 \\
\hline 8 & June 15-July 1 & 53,265 & 1054.75 & 42.19 & 35 \\
\hline 9 & July 1-July 15 & 38,786 & 768.05 & 30.72 & 23 \\
\hline 10 & July 15-August 1 & 12,574 & 249 & 9.96 & 27 \\
\hline 11 & August 1-August 15 & 8130 & 161 & 6.44 & 19 \\
\hline 12 & August $15-$ September 1 & 4440 & 87.93 & 3.52 & 14 \\
\hline 13 & September $1-$ September 15 & 2887 & 57.17 & 2.29 & 15 \\
\hline 14 & September 15-October 1 & 4412 & 87.38 & 3.49 & 12 \\
\hline 15 & October 1-October 15 & 4604 & 91.17 & 3.64 & 8 \\
\hline 16 & October $15-$ November 1 & 6060 & 120.01 & 4.8 & 7 \\
\hline 17 & November $1-$ November 15 & 13,269 & 262.75 & 10.51 & 10 \\
\hline
\end{tabular}

useful information for timely planning of resources allocation, trade restrictions and lock down.

By STSS, COVID-19 cases' pattern in 6 different classes was 0 to 5,5 to 10,10 to 15,15 to 20,20 to 30 and $>30$ from March to November 2020 (Fig. 3). These classes show the risk of exposing the spatial spread of COVID-19 in relation to various districts of Punjab, based on district population as well as environmental factors which may control the distribution of the cases. The maximum patients returning to the homeland, including friends, families and relatives (who have been in close contact with incubation carriers), were reported on a daily basis as an observational analysis. We highlight all districts, which are known as the initial main hotspots of the epidemics in the study area. District Lahore is known to have the first Punjab case of COVID-19, which was presented by current travellers in China, leading to deadly epidemics in nursing homes as well as the surrounding area. Figure 3 shows that districts Lahore and Multan have greatest values of RR of COVID-19 (>30) in the study area. Various districts like Mianwali, Atock, Chakwal, Khushab, Chiniot, Jhang, TT Singh, Khanewal, Sahiwal, Okara, Pakpattan and Bahawalnagar indicated very less RR values of COVID-19. Areas with an RR of 0 are more transparent to focus than on the areas with a raised risk that "contribute" to the emerging clusters.

\section{Effects of COVID-19 on agriculture}

According to the survey, most respondents (43\%) perceived that COVID-19 affected the agriculture in study area
(Fig. 4). Approximately half anticipated that living effects would be "moderate" or "severe". The projected severity of livelihood effects was dependable across female and male respondents. Farmers involved in petty trade and everyday casual labour had the greatest negative view, with one-fourth expecting severe effects on agriculture. Most residents $(57 \%)$ observed that their health had particularly changed due to COVID-19 lockdown (Fig. 5). Similarly, almost $70 \%$ farmers had the opinion that their economic conditions are changed during these days, but the only $22 \%$ residents said that economic conditions had not changed in Pakistan (Suleri 2020). By Jamal (2020), mostly (68\%) farmers observed that agricultural yield was affected to a great extent due to lockdown during April and May in Pakistan. Furthermore, almost $27 \%$ of the respondents reported that agriculture yield did not change during lockdown. About $62 \%$ of the respondents responded that land holding was affected by COVID-19 (Fig. 6).

Wheat is the major crop grown in study area during the Rabi season, and it is produced by almost $88 \%$ of respondents during April and May. Mostly farmers indicated that COVID-19 affected during sowing to cotton and rice due to the highest no of cases and RR values during month of May and June. Almost 8 percent respondents grew maize, which is used commonly for poultry feed; almost 4 percent of respondents raised vegetables and other crops. The COVID-19 had mostly affected the wheat and maize harvest. Mostly farmers (86\%) stated that they could complete harvesting during the last week of April and therefore had faced extreme effects due to COVID-19 as shown in Fig. 7. Almost 
Fig. 3 Mean of relative risk (RR) values of COVID-19 using STSS during 15th March to 15 th November 2020 in different districts of Punjab

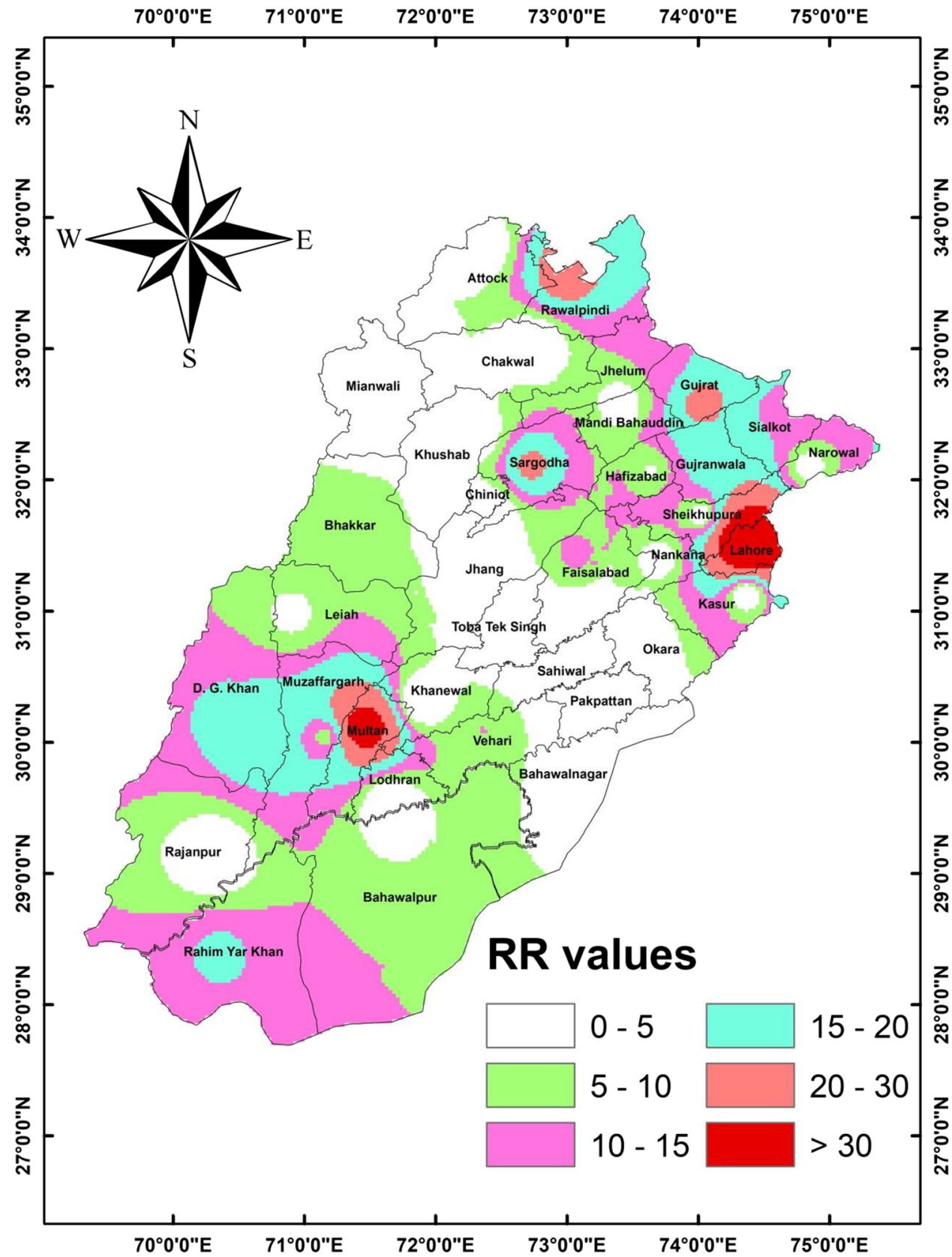

$9 \%$ of respondents reported that they had faced moderated effects on wheat and $5 \%$ faced some effects during COVID19. The COVID-19 had also effects on vegetable as well as other crops. Similarly, 60\% respondents reported that they faced extreme effects on vegetables and other crops due to COVID-19. Almost $45 \%$ of fruit and vegetable cultivators got very low prices, and $55 \%$ could not visit the markets due to COVID-19. Mostly farmers indicated that COVID-19 was the key reason of these problems. Most of the wheat and other crops harvest were disturbed due to COVID-19-related problems. However, milk producers were affected due of COVID-19, as dealers were unable to buy milk from the dairy farms. Mostly markets and restaurants were closed; the milk demand distorted resulting in less milk prices. The $35 \%$ of farmers stated that they were facing disruptions in receiving and purchasing fertilizer and seed from market during COVID-19. Respondents were facing extreme effects in the supply of the different farm inputs during COVID-19: for example, the delivery and purchase of fertilizer by $81 \%$, seed by $90 \%$ and pesticides by $86 \%$ (Fig. 8 ).

According to Jamal (2020), almost 70 percent of Pakistan's farmers depend on farm labourers, who come from the less income regions before the harvesting period. But during this season, they could not manage it due to COVID-19 lockdown (Rasheed et al. 2021). A farmer from Punjab province is running from pillar to post to arrange labour for the wheat 


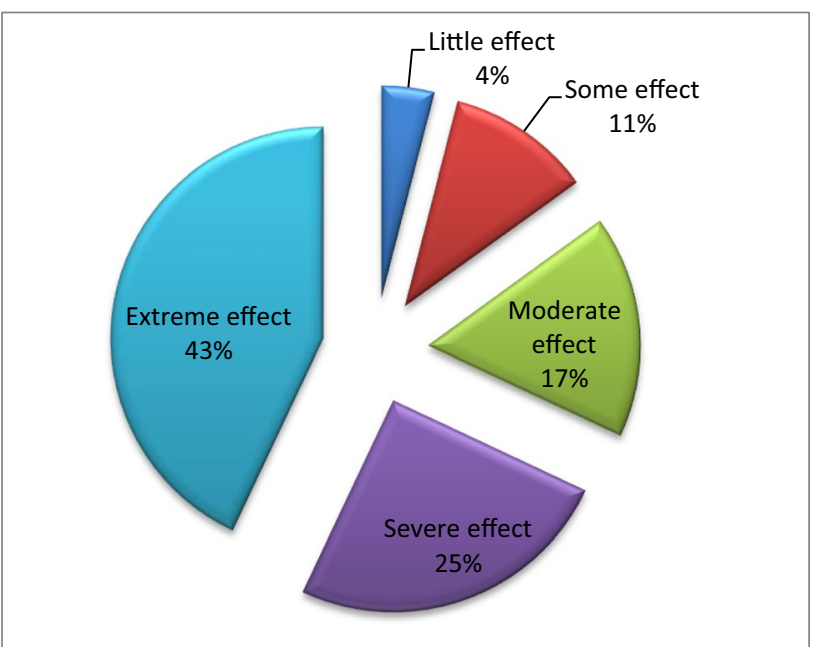

Fig. 4 Response of farmers about agriculture during COVID-19 in Punjab harvesting, which in his area is set to start next week. This farmer is one of hundreds of thousands of farmers, dreadfully searching for labour for wheat harvest, mostly in Punjab and southern Sindh (the two bread-baskets for Punjab). The cultivation area for wheat has already decreased due to the changing climate in current years. The interruption in harvesting could decrease enormous amounts of winter crops, mainly wheat, in study area. "Several labourers have personally told that they are scared of getting infected".

Farmers could not avail transportation for transporting fresh food to urban and local markets. Furthermore, day meal packages in schools were disturbed because food assistance could not be supplied to the schools (Sahoo and Rath 2020). Effects of COVID-19 on our agriculture as well as food system need to be informed and accelerated by practices and ideas all over the world (Goddard 2020). By work in collaboration to bring partnerships and
Fig. 5 Farmer response about health and economics during lockdown in Punjab
Fig. 6 Response of farmers about land holding and agriculture yield during COVID-19 in Punjab
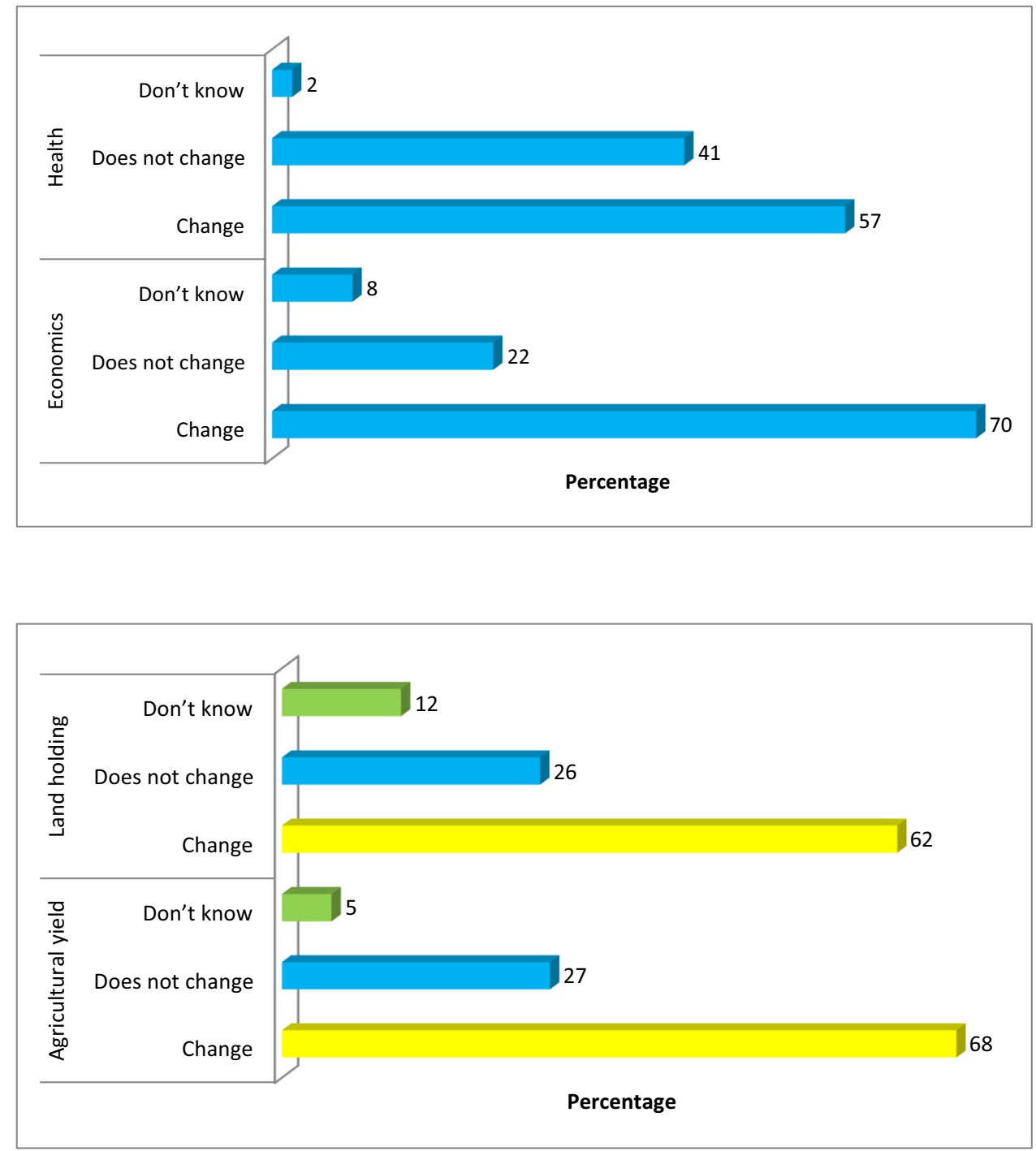
Fig. 7 Effect of COVID-10 on various crops and milk during COVID-19 in Punjab

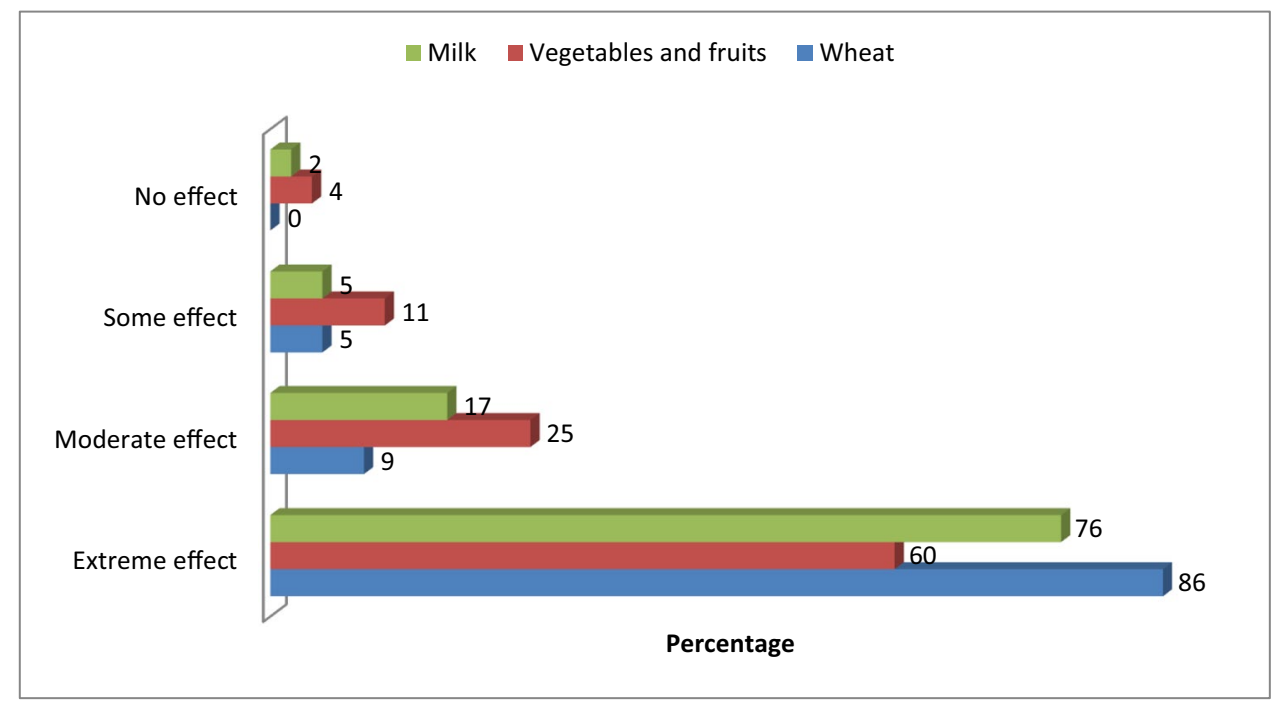

Fig. 8 Attributed farm input price during COVID-19 in Punjab

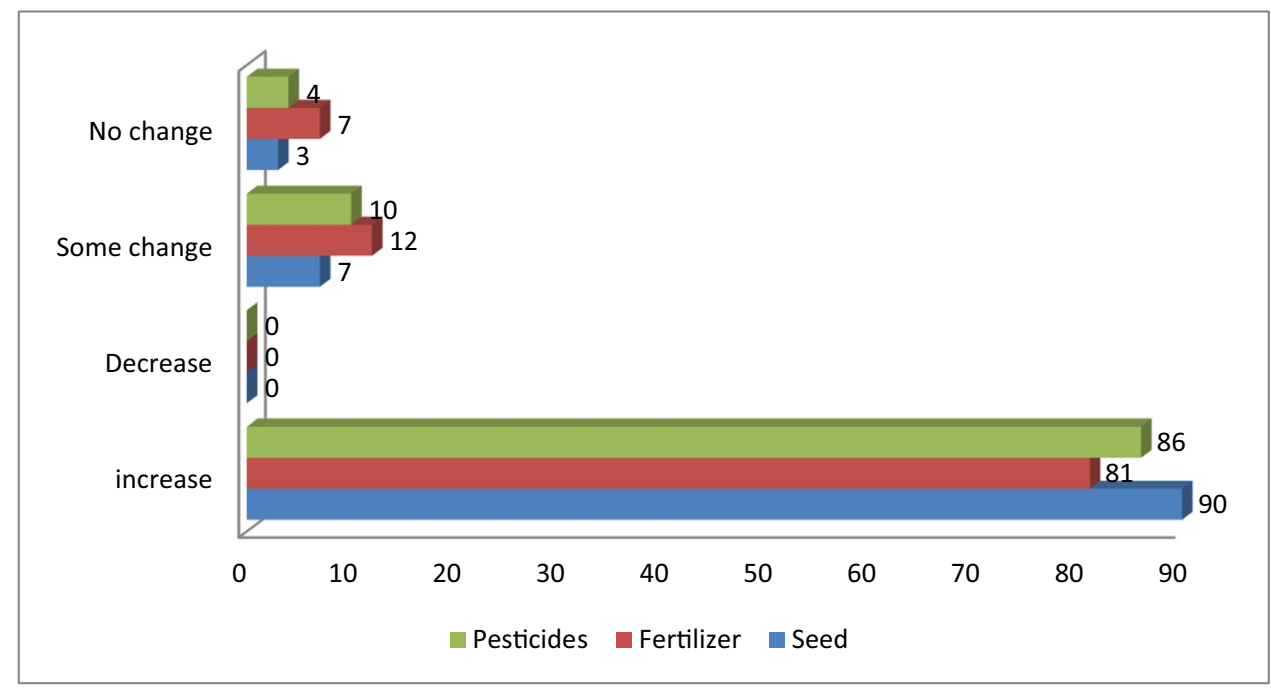

ideas together, the worldwide community (as well as one of the greatest susceptible people in Punjab) has a much stronger chance of coping the effects of COVID-19 on food security as well as defending the food production and agriculture. By Gray (2020), due to increase in food price during lockdown, different countries are increasing special labours to keep agriculture securely running as a vital business, markets being provided in nutritious and adorable food and customers still able to purchase and access food despite income losses and movement restrictions. Farmers must have access to markets without any discontinuation. This can be achieved if maximum government procurement and private markets work side by side. Small dairy and poultry farmers should be provided more targeted help, because the input supply and market access problems of these businesses during pandemic are of urgent nature. Farmers and other agriculture-related workers should be involved in the government's social protection programs and support packages during the COVID-19 crisis. The government should encourage trade by evading import constraints and export bans. The government can also play an important role by confirming control on price of food commodities.

\section{Effects of COVID-19 on food supply chain}

COVID-19 has a serious threat for those who put the food on our plates; it has disturbed the complete food supply 
Fig. 9 Response of farmers about food prices and access to market during COVID-19 in Punjab

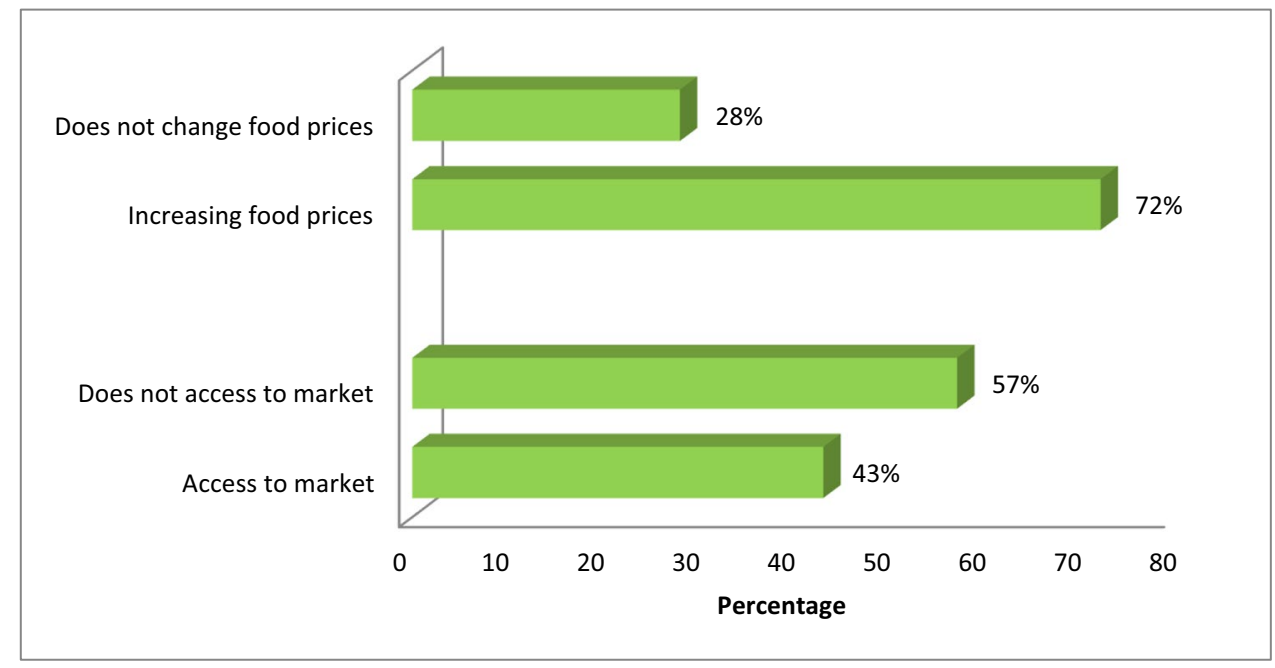

chain comprising crop producers, transporters, processors, sellers, marketers and customers. According to the survey conducted, mostly farmers (72\%) observed an increase in food prices. However, $28 \%$ respondents perceived that food prices have not been changed during lockdown. Most people $(57 \%)$ reported that they could not access to markets and stores during lockdown. However, $43 \%$ of respondents experienced being able to have regular access to markets and grocery stores during COVID-19 (Fig. 9). The main issues of limiting market access were a combination of closing of markets, movement constraints, as well as concerns about leaving the household. Their main restrictions to markets access were transport limits as well as adult members in the house being self-quarantined.

The accessibility of food and other necessities of life were less than normal; on the other hand, very few farmers showed that vital food items were unavailable. Most respondents (47\%) perceived that fresh food was available during lockdown (Table 2). However, fresh food seemed slightly less accessible than staple food. Hygiene and medicines were mostly available in stores and market, with 3-7\% of farmers showed that these items were unavailable. Mostly farmers showed that medicines were mostly available in market, but only $3 \%$ were of the view that these were not available during lockdown. According to WFP (world food program) 2020b), almost 23 percent people in drought-prone

Table.2 Availability of items in stores in percentage during lockdown in Punjab

\begin{tabular}{lllll}
\hline & Fresh food & Medicines & Hygiene & Staple food \\
\hline Available & 47 & 72 & 66 & 80 \\
Partially available & 42 & 25 & 23 & 15 \\
Not available & 9 & 3 & 7 & 5 \\
Don't know & 2 & 0 & 4 & 0 \\
\hline
\end{tabular}

zones of world are under stress, while 51 percent people in these regions are in worse conditions or crisis.

In Punjab, vegetable and fruit markets were crushed by COVID-19, starting in April 2020. Due to closing of bars, schools and restaurants, crop growers and suppliers were forced to shift deliveries completely from the food services to the retail channel. COVID-19 could potentially affect the smooth function of transport at about every step along the food supply chain. COVID-19 disease could limit the accessibility of skilled employees in the transport sector in food supply chain. This supply chain contains inputs to production area to storage, to manufacturers and processors, as well as to retailers and distributors. Limitations in agricultural labours movements might increase food prices and limit their availability. The countries which consume much imported food will have to bear increased food prices due to the depreciation in their local currency value as compared to the US dollar (Imran 2020).

Before COVID-19 disease, 820 million people were under-nourished, with two billion people facing food diffidence all over the globe (Saha et al. 2020). By Sumner et al. (2020), numerous million peoples are living dangerously nearby the poverty line: They have deficiency of physical as well as economic means to obtain food due to the supply disruptions, self-isolation, lost income and movement. For instance, $30 \%$ of Pakistanis are unable to afford more than one meal a day; the country's Prime Minister has given the warning that an interruption of economic activity due to lockdown will be extremely detrimental. The lockdowns by COVID-19 and its disruptions have revealed the fragility of people's access to vital services and goods (Chen et al. 2020). In food and health systems, serious inequalities and weaknesses have been highlighted. Food systems, the people sustaining them and public goods they distribute, have been under-protected and under-valued. The universal weaknesses shown by COVID-19 will be further affected due to change 
in climate in next few years. According to Galanakis (2020), COVID-19 has adversely impacted the food systems and supplies that must be observed. It is vital to take all essential actions to remove main barriers to procurement of food during lockdowns, while ensuring consumers and workers security.

The COVID-19 disaster has excelled an attention on the susceptibilities of food security on 3 faces: The first one is that industrial agriculture is creating loss of habitat and could develop conditions conducive for viruses to emerge and spread. At second place, a range of distractions are challenging the resilience of food supply chains. Thirdly, most people are living perpetually on the dangerous poverty, malnutrition and cusp of hunger and are extremely susceptible to the effects of a worldwide decline.

\section{Conclusion}

The objective of this research was to study the effects of COVID-19 in Punjab, Pakistan; this was achieved by using STSS. Due to maximum observed cases 53,265 and RR values 42.19 during June 15th-July 1st, 2020, mostly farmers faced many difficulties during the growing of cotton and rice. However, it was not necessary that by increasing the number of active cases in the whole Punjab, the RR risk would be higher for all the districts. Mostly farmers stated that wheat harvesting, as well as selling, was disturbed due to the effects of the limited movement of goods forced due to the COVID-19 in Punjab. According to the survey conducted, mostly farmers (72\%) observed an increase in food prices in study area during lockdown. Accessibility of medicines, hygiene and fresh food appeared to be less than regular form in study area. Mostly people (57\%) reported that they could not access to markets and stores and almost $43 \%$ of respondents experienced being able to have regular access to markets and grocery stores during COVID-19 in study area. In conclusion, COVID-19 will have longer lasting impacts on agriculture sector and food supply chains in Punjab. Our results will help for increasing the capacity of local government and farmers to implement sound strategies for improvement of food and agriculture during COVID-19. It is also an essential for the current application of policies for policy-makers on easy and adequate availability of farming evidence for the local farmers to the improvement of agriculture and food security. The government will have to collaborate and innovate for agriculture policy and food security. This will allow best managing their agri-food exports and imports, ensure that people have access to food and decrease the risks related to food trade bans.

There are various improvements which could be used for ensuring food security and agriculture in future:
1. Agricultural mechanisation should be available on sustained basis to increase crop production; youth contribution should be encouraged and more jobs should be created. Production of tractors as well as other modern tools should be stimulated while making it obtainable at rational price.

2. Farmers must have access to markets without any discontinuation. This can be achieved if maximum government procurement and private markets work side by side.

3. Involving Pakistan's farming with engineering, technology, e-commerce and manufacturing, can offer assembly benefits like creating jobs, improving lives and increasing economy.

4. The government should encourage trade by evading import constraints and export bans. The government can also play an important role by confirming control on price and food security.

Author contribution $\mathrm{SH}, \mathrm{MM}$ and $\mathrm{WN}$ proposed the main concept and highly involved in write-up. AA, SH, MM and HUF assisted in data analysis and preparation spatial map. MA and $\mathrm{WN}$ are involved to write-up and review. GMS, BM, MT, SF and SP involved to review, editing, review and English grammar correction.

Availability of data The datasets used and/or analysed during the current study are available in the article/from the corresponding author on request.

\section{Declarations}

Ethics approval Not applicable.

Consent to Participate Not applicable.

Consent for publication Not applicable.

Competing interests The authors declare no competing interests.

\section{References}

Ahmad D, Afzal M, Rauf A (2020) Environmental risks among rice farmers and factors influencing their risk perceptions and attitudes in Punjab, Pakistan. Enviro Sci Poll Res 1-12https://doi.org/10. 1007/s11356-020-08771-8

Ahmed M, Aslam MA, Hayat R, Nasim W, Akmal M, Mubeen M, Ahmad S (2022) Nutrient dynamics and the role of modeling. In Building Climate Resilience in Agriculture (297-316). Springer, Cham. https://doi.org/10.1007/978-3-030-79408-8_19

Akram R. et al. (2022) Research on Climate Change Issues. In: Jatoi W.N., Mubeen M., Ahmad A., Cheema M.A., Lin Z., Hashmi M.Z. (eds) Building climate resilience in agriculture. Springer, Cham. https://doi.org/10.1007/978-3-030-79408-8_17 
Ali A, Rahut DB (2020) Localized floods, poverty and food security: empirical evidence from rural Pakistan. Hydro 7(1):2. https://doi. org/10.3390/hydrology7010002

Alvarez-Mendoza CI, Teodoro A, Freitas A, Fonseca J (2020) Spatial estimation of chronic respiratory diseases based on machine learning procedures - an approach using remote sensing data and environmental variables in quito. Ecuador Appl Geo 123:102273. https://doi.org/10.1016/j.apgeog.2020.102273

Arab-Mazar Z, Sah R, Rabaan AA, Dhama K, Rodriguez-Morales AJ (2020) Mapping the incidence of the COVID-19 hotspot in Iranimplications for travellers. Travel Medicine Infectious Dis. https:// doi.org/10.1016/j.tmaid.2020.101630

Arndt C, Davies R, Gabriel S, Harris L, Makrelov K, Robinson S, Anderson L (2020) Covid-19 lockdowns, income distribution, and food security: An analysis for South Africa. Glob Food Sec 26:100410

Ayra H (2020) Food security, the farmers of Pakistan and coronavirus. Arab news March 29, 2020. https://www.arabnews.pk/node/16494 96. Accessed July 2020

Béné C (2020) Resilience of local food systems and links to food security-a review of some important concepts in the context of COVID-19 and other shocks. Food Se. 1-18

Bizoza A, Sibomana S (2020) Indicative socio-economic impacts of the novel coronavirus (Covid-19) outbreak in Eastern Africa: Case of Rwanda. Available at SSRN 3586622

Boughton D, Goeb J, Lambrecht I, Mather D, Headey DD (2020) Strengthening smallholder agriculture is essential to defend food and nutrition security and rural livelihoods in Myanmar against the COVID-19 threat: Elements for a proactive response (Vol. 2). Intl Food Policy Res Inst

Boulos MNK, Geraghty EM (2020) Geographical tracking and mapping of coronavirus disease COVID-19/severe acute respiratory syndrome coronavirus 2 (SARS-CoV-2) epidemic and associated events around the world: how 21 st century GIS technologies are supporting the global fight against outbreaks and epidemics. https://doi.org/10.1186/s12942-020-00202-8

Chan JF, Yuan S, Kok KH, To KK, Chu H, Yang J, Xing F, Liu J et al (2020) A familial cluster of pneumonia associated with the 2019 novel coronavirus indicating person to-person transmission: a study of a family cluster. Lancet 395(10223):514-523. https:// doi.org/10.1016/S0140-6736(20)30154-9

Chen Q, Liang M, Li Y, Guo J, Fei D, Wang L, Wang J (2020) Mental health care for medical staff in China during the COVID-19 outbreak. The Lancet Psychiatry 7(4):e15-e16

Deaton BJ, Deaton BJ (2020) Food security and Canada's agricultural system challenged by COVID-19. Canadian J Agri Eco/revue Canadienne D'agroeconomie. https://doi.org/10.1111/cjag.12227

Desjardins MR, Hohl A, Delmelle EM (2020) Rapid surveillance of COVID-19 in the United States using a prospective space-time scan statistic: detecting and evaluating emerging clusters. Appl Geo 102202https://doi.org/10.1016/j.apgeog.2020.102202

Din MSU, Mubeen M, Hussain S, Ahmad A, Hussain N, Ali M A, Nasim W (2022) World nations priorities on climate change and food security. In Building Climate Resilience in Agriculture (365384). Springer, Cham. https://doi.org/10.1007/978-3-030-794088_22

Dlamini WM, Dlamini SN, Mabaso SD, Simelane SP (2020) Spatial risk assessment of an emerging pandemic under data scarcity: a case of COVID-19 in Eswatini. Appl Geo 125:102358. https://doi. org/10.1016/j.apgeog.2020.102358

Galanakis CM (2020) The food systems in the era of the coronavirus (COVID-19) pandemic crisis. Foods 9(4):523

Goddard E (2020) The impact of COVID-19 on food retail and food service in Canada: preliminary assessment. Canadian J Agri Eco/ Revue canadienne d'agroeconomie
Gray R (2020) Agriculture, transportation, and the COVID-19 crisis. Canadian J Agri Eco/Revue canadienne d'agroeconomie.

Guo YR, Cao QD, Hong ZS, Tan YY, Chen SD, Jin HJ, Tan KS, Wang DY, Yan Y (2020) The origin, transmission and clinical therapies on coronavirus disease 2019 (COVID-19) outbreak - an update on the status. Military Medical Res 7(1):11. https://doi.org/10.1186/ s40779-020-00240-0

Hafiz H, Oei SY, Ring DM, Shnitser N (2020) Regulating in pandemic: evaluating economic and financial policy responses to the coronavirus crisis. Boston College Law School Legal Studies Res Paper, (527)

Hohl A, Delmelle EM, Desjardins MR, Lan Y (2020) Daily surveillance of COVID-19 using the prospective space-time scan statistic in the United States. Spatial Spatio-Temporal Epidemiology 34:100354. https://doi.org/10.1016/j.sste.2020.100354

Hussain S (2018) Land Use/Land Cover Classification by Using Satellite NDVI Tool for Sustainable Water and Climate Change in Southern Punjab. COMSATS University Islamabad. https://doi. org/10.13140/RG.2.2.32363.69923

Hussain S, Amin A, Mubeen M, Khaliq T, Shahid M, Hammad HM, Nasim W (2022) Climate Smart Agriculture (CSA) Technologies. In Building Climate Resilience in Agriculture (319-338). Springer, Cham. https://doi.org/10.1007/978-3-030-79408-8_20

Hussain S, Karuppannan S (2021) Land use/land cover changes and their impact on land surface temperature using remote sensing technique in district Khanewal, Punjab Pakistan. Geol Eco Landscape 1-13https://doi.org/10.1080/24749508.2021.19232 72

Hussain S, Ahmad A, Wajid A, Khaliq T, Hussain N, Mubeen M, Farid H, Imran M, Hammad HM, Awais M, Ali A, Aslam M, Amin A, Akram R, Amanet K, Nasim W (2020a) Irrigation Scheduling for Cotton Cultivation. In Cotton Production and Uses (59-80). Springer, Singapore. https://doi.org/10.1007/ 978-981-15-1472-2_5

Hussain S, Mubeen M, Ahmad A, Akram W, Hammad HM, Ali M, Masood N, Amin A, Farid HU, Sultana SR, Fahad S (2020b) Using GIS tools to detect the land use/land cover changes during forty years in Lodhran District of Pakistan. Environ Sci Pollut Res 1:1-17. https://doi.org/10.1007/s11356-019-06072-3

Hussain S, Mubeen M, Akram W, Ahmad A, Habib-ur-Rahman M, Ghaffar A, Amin A, Awais M, Farid HU, Farooq A, Nasim W (2020c) Study of land cover/land use changes using RS and GIS: a case study of Multan district. Pakistan Environ Monit Assess 192(1):2. https://doi.org/10.1007/s10661-019-7959-1

Imran M (2020) Online conference on impact of coronavirus on agri sector. The news. April 22, 2020.https://www.thenews.com.pk/ print/647738-online-conference-on-impact-of-coronavirus-onagri-sector. Accessed Aug 2020

Islam MS, Fahad S, Hossain A, Chowdhury MK, Iqbal MA, Dubey A, Sabagh AE (2021) Legumes under drought stress: plant responses, adaptive mechanisms, and management strategies in relation to nitrogen fixation. In Engineering Tolerance in Crop Plants Against Abiotic Stress (179-207). CRC Press

Jamal S (2020) How will COVID-19 affect Pakistan farmers, food system? Gulf news Published: May 01, 2020. https://gulfnews. com/world/asia/pakistan/how-will-covid-19-affect-pakistanfarmers-food-system-1.71196910. Accessed Aug 2020

Kansiime MK, Tambo JA, Mugambi MI, Bundi MM, Kara A, Owuor MC (2020) COVID-19 implications on household income and food security in Kenya and Uganda: findings from a rapid assessment. World Develop 105199

Karunanidhi D, Aravinthasamy P, Deepali M, Subramani T, Shankar K (2021) Groundwater pollution and human health risks in an industrialized region of southern India: impacts of the COVID19 lockdown and the monsoon seasonal cycles. Archives 
Environ Contamination Toxicology 80(1):259-276. https://doi. org/10.1007/s00244-020-00797-w

Karuppasamy MB, Seshachalam S, Natesan U et al (2020) Air pollution improvement and mortality rate during COVID19 pandemic in India: global intersectional study. Air Qual Atmos Health 13:1375-1384. https://doi.org/10.1007/ s11869-020-00892-w

Khaliq MA, Ali S, Kamran A, Qasrani TB (2020) Opinion on impact of Covid-19 lockdown on agriculture, food security and livelihoods in Pakistan

Khan N, Fahad S, Naushad M, Faisal S (2020a) COVID-2019 Locked down impact on dairy industry in the world. Available at SSRN 3616325

Khan N, Fahad S, Naushad M, Faisal S (2020b) Effects of social stigma on the sick people of Covid-2019 in the community of the world. Available at SSRN 3600579

Khan N, Naushad M, Akbar A, Faisal S, Fahad S (2020c) Critical review of COVID-2019 in Pakistan and its impact on Pakistan economy. Available at SSRN 3629718

Khan N, Naushad M, Akbar A, Faisal S, Fahad S (2020d) Critical review of COVID-2019 in Italy and impact on its economy. Available at SSRN 3632007

Kreutz R, Algharably EAEH, Azizi M, Dobrowolski P, Guzik T, Januszewicz A, Burnier M (2020) Hypertension, the renin-angiotensin system, and the risk of lower respiratory tract infections and lung injury: implications for COVID-19European Society of Hypertension COVID-19 Task Force Review of Evidence. Cardiovascular Research

Kumar A, Padhee AK, Kumar S (2020) How Indian agriculture should change after COVID-19. Food Security 12(4):837-840

Lakhani A (2020) Which Melbourne metropolitan areas are vulnerable to COVID-19 based on age, disability and access to health services? Using spatial analysis to identify service gaps and inform delivery. J Pain Symptom Manage. https://doi.org/10.1016/j.jpain symman.2020.03.041

Latif A (2020) Pakistan to ease lockdown amid COVID-19. 05.05.2020. https://www.aa.com.tr/en/asia-pacific/pakistan-to-ease-lockdownamid-covid-19/1829390

Majeed M, Tariq A, Anwar MM, Khan AM, Arshad F, Shaukat S (2021) Monitoring of land use-land cover change and potential causal factors of climate change in Jhelum district, Punjab, Pakistan, through GIS and multi-temporal satellite data. Land 10(10):1026. https://doi.org/10.3390/land10101026

Malik K, Meki M, Morduch J, Ogden T, Quinn S, Said F (2020) COVID-19 and the future of microfinance: evidence and insights from Pakistan. Oxford Review of Economic Policy, Forthcoming

Martines MR, Ferreira RV, Toppa RH, Assunção LM, Desjardins MR, Delmelle EM (2021) Detecting space-time clusters of COVID-19 in Brazil: mortality, inequality, socioeconomic vulnerability, and the relative risk of the disease in Brazilian municipalities. J Geo Systems 23(1):7-36. https://doi.org/10.1007/s10109-020-00344-0

Masood N, Akram R, Fatima M, Mubeen M, Hussain S, Shakeel M, Nasim W (2022). Insect pest management under climate change. In Building Climate Resilience in Agriculture (225-237). Springer, Cham. https://doi.org/10.1007/978-3-030-79408-8_15

Masrur A, Yu M, Luo W, Dewan A (2020) Space-time patterns, change, and propagation of COVID-19 risk relative to the intervention scenarios in Bangladesh. Inter J Environ Res Public Health 17(16):5911. https://doi.org/10.3390/ijerph17165911

Mehmood K, Bao Y, Abrar MM, Petropoulos GP, Soban A, Saud S, Fahad S (2021) Spatiotemporal variability of COVID-19 pandemic in relation to air pollution, climate and socioeconomic factors in Pakistan. Chemosphere 271:129584. https://doi.org/10. 1016/j.chemosphere.2021.129584

Mhlanga D, Ndhlovu E (2020) Socio-economic implications of the COVID-19 pandemic on smallholder livelihoods in Zimbabwe
Miller M (2020) 2019 Novel coronavirus COVID-19 (2019-nCoV) data repository. Bulletin-Association Canadian Map Libraries and Archives (ACMLA) 164:47-51

Mohan Viswanathan P, Sabarathinam C, Karuppannan S, Gopalakrishnan G (2021) Determination of vulnerable regions of SARS-CoV-2 in Malaysia using meteorology and air quality data. Environ Develop Sustain 1-27https://doi.org/10.1007/ s10668-021-01719-z

Mollalo A, Vahedi B, Rivera KM (2020) GIS-based spatial modeling of COVID-19 incidence rate in the continental United States. Sci Total Environ 138884https://doi.org/10.1016/j.scitotenv.2020. 138884

Mubeen M, Bano A, Ali B, Islam ZU, Ahmad A, Hussain S, Fahad S, Nasim W (2021) Effect of plant growth promoting bacteria and drought on spring maize (Zea mays L.). Pak J Bot 53(2). https:// doi.org/10.30848/PJB2021-2(38)

Murugesan B, Karuppannan S, Mengistie AT, Ranganathan M, Gopalakrishnan G (2020) Distribution and trend analysis of COVID-19 in India: geospatial approach. J Geogr Stud 4(1):19. https://doi.org/10.21523/gcj5.20040101

Murugesan B, Karuppannan S, Mengistie AT, Ranganathan M, Gopalakrishnan G (2020) Distribution and trend analysis of COVID-19 in India: geospatial approach. J Geo Stud 4(1):1-9. https://doi.org/10.21523/gcj5.20040101

Naz S, Fatima Z, Iqbal P, Khan A, Zakir I, Ullah H, Ahmad S (2022) An introduction to climate change phenomenon. In Building Climate Resilience in Agriculture (3-16). Springer, Cham. https://doi.org/10.1007/978-3-030-79408-8_1

Niles MT, Bertmann F, Morgan EH, Wentworth T, Biehl E, Neff R (2020) Food access and security during coronavirus: a Vermont study

PBS (2020) Pakistan bureau of statistics Government of Punjab. http://www.pbs.gov.pk/. Accessed Dec 2020

Rasheed R, Rizwan A, Javed H, Sharif F, Zaidi A (2021) Socioeconomic and environmental impacts of COVID-19 pandemic in Pakistan-an integrated analysis. Environ Sci Pollut Res 28(16):19926-19943. https://doi.org/10.1007/ s11356-020-12070-7

Rezaei M, Nouri AA, Park GS, Kim DH (2020) Application of geographic information system in monitoring and detecting the COVID-19 outbreak. Iranian J Public Health 49:114-116

Richards TJ, Rickard B (2020) COVID-19 impact on fruit and vegetable markets. Canadian J Agri Eco/Revue canadienne d'agroeconomie

Sabagh AE, Hossain A, Islam MS, Iqbal MA, Fahad S, Ratnasekera D, Llanes A (2020) Consequences and mitigation strategies of heat stress for sustainability of soybean (Glycine max L. Merr.) production under the changing climate. In Plant Stress Physiology. IntechOpen. https://doi.org/10.5772/intechopen. 92098

Saha A, Gupta K, Patil M (2020) Monitoring and epidemiological trends of coronavirus disease (COVID-19) Around The World

Sahoo PP, Rath S (2020) Potential impact of corona virus on agriculture sector. Biotica Res Today 2(4):64-65

Sarfo AK, Karuppannan S (2020) Application of geospatial technologies in the COVID-19 fight of Ghana. Trans Indian Natl Acad Eng 5:193-204. https://doi.org/10.1007/s41403-020-00145-3

Shahzad MA, Qing P, Rizwan M, Razzaq A, Faisal M (2021) COVID-19 pandemic, determinants of food insecurity, and household mitigation measures: a case study of Punjab, Pakistan. In Healthcare (Vol. 9, No. 6, p. 621). Multidisciplinary Digital Publishing Institute. https://doi.org/10.3390/healthcare 9060621

Shankar K, Gnanachandrasamy G, Mahalakshmi M, Devaraj N, Prasanna MV, Chidambaram S, Thilagavathi R (2021) Meteorological parameters and COVID-19 spread-Russia a case 
study. In Environ Resilience Transformation Times of COVID19 (179-190). Elsevier. doi: https://doi.org/10.1016/B978-0323-85512-9.00033-4

Siche R (2020) What is the impact of COVID-19 disease on agriculture? Scientia Agropecuaria 11(1):3-6

Spinelli A, Pellino G (2020) COVID-19 pandemic: perspectives on an unfolding crisis. Br J Surg 10

Stephens EC, Martin G, van Wijk M, Timsina J, Snow V (2020) Impacts of COVID-19 on agricultural and food systems worldwide and on progress to the sustainable development goals. Agri Sys 183:102873

Suleri AQ (2020) Corona and the rural economy. The news. April 4, 2020. https://www.thenews.com.pk/print/638984-corona-andthe-rural-economy

Sumner A, Hoy C, Ortiz-Juarez E (2020) Estimates of the impact of COVID-19 on global poverty. UNU-WIDER $800-9$

Sun J, He WT, Wang L, Lai A, Ji X, Zhai X, Veit M (2020) COVID19: epidemiology, evolution, and cross-disciplinary perspectives. Trends in Molecular Medicine

WFP (world food program) (2020a) Global Report on Food Crises. 20 April 2020. https://www.wfp.org/publications/ 2020-global-report-food-crises

WFP (world food program) (2020b) Global Report on Food Crises reveals scope of food crises as COVID-19 poses new risks to vulnerable countries. 21 April 2020. https://www.wfp.org/news/ global-report-food-crises-reveals-scope-food-crises-covid-19poses-new-risks-vulnerable

WHO (World Health Organization) (2020) Coronavirus disease 2019 (COVID-19): situation report, 72. WHO

Wu F, Zhao S, Yu B, Chen YM, Wang W, Song ZG, Hu Y, Tao ZW, Tian JH et al (2020) A new coronavirus associated with human respiratory disease in China. Nature 579:265-269. https://doi.org/ 10.1038/s41586-020-2008-3

Zhang S, Wang S, Yuan L, Liu X, Gong B (2020) The impact of epidemics on agricultural production and forecast of COVID19. China Agri Eco Review

Zhou C, Su F, Pei T, Zhang A, Du Y, Luo B Song C (2020) COVID-19: challenges to GIS with big data. Geo Sustain

Zhu N, Zhang D, Wang W, Li X, Yang B, Song J, Zhao X, Huang B, Shi W, Lu R, Niu P, Zhan F, Ma X, Wang D, Xu W, Wu G, Gao GF (2019) Tan W (2020) A novel coronavirus from patients with pneumonia in China. The New England J Medicine 382(8):727733. https://doi.org/10.1056/NEJMoa2001017

Publisher's Note Springer Nature remains neutral with regard to jurisdictional claims in published maps and institutional affiliations. 